\title{
The Banyamulenge people: Their
}

\section{angst, honour and shame in the light of the Matthean Community}

\author{
S L Rukundwa (Democratic Republic of Congo) ${ }^{1}$ \\ Department of New Testament Studies \\ University of Pretoria
}

\begin{abstract}
This article focuses on two theological contributions based on a social analysis of the Gospel of Matthew and its application to the Banyamulenge community in the Democratic Republic of Congo: the work of Overman $(1990,1996)$ on the formation of the Matthean community and its identity versus formative Judaism in their cultural setting; the work of Neyrey (1998) on honour and shame codes in the social context of the Matthean community. The article analyses the commitment of the first Banyamulenge Christian believers in light of the cultural codes of honour and shame, which were also part of the community's survival mechanisms. The life story of Madam Kibihira is compared to other women entries in Jesus' genealogy (Mt 1) and the Canaanite woman (Mt 15). Madam Kibihira was the first woman who became Christian and also the first Banyamulenge victim for her faith in Christ. The article argues that faith earns honour regardless of social status.
\end{abstract}

\section{INTRODUCTION}

The question why Matthew should be chosen as a book of reference may well be asked. Seen from a socio-political perspective, the Gospel of Matthew contains the most fascinating stories that create room for a cross-cultural message. Matthew is courageous enough for his introductory chapter to present his main character as a "cultural figure" and as part of Jewish ancestry lineage. He is a King, but from us; he is God, but for us and with us.

\footnotetext{
${ }^{1}$ This article is based on research done for the MA degree in theology, entitled "The Banyamulen-ge Community seen from social and Biblical perspective", under the supervision of Prof Dr P A Geyser. The degree was conferred by the University of Pretoria (2003). Rev Sebi L Rukundwa is a PhD student in the Department of New Testament Studies at the Faculty of Theology, University of Pretoria, under the supervision of Prof Dr Andries G van Aarde.
} 
Matthew's introduction has a strong appeal and persuasive powers for the Banyamulenge culture in which gods are presented in the form of human beings. ${ }^{2}$ Secondly, the most crucial point Matthew is trying to make is the community ownership of the revealed secret in the fulfilment of prophecies: the Messiah, Immanuel has come. Thirdly, the Messiah is to fulfil the will of God to all nations. It is in this regard that the trouble of honour and shame sets in between the Matthean community ${ }^{3}$ and its opponents (Pharisees, scribes and priests that formed the Judaism community, or formative Judaism $)^{4}$. The conflict that arose between the Matthean and Judaism communities resulted from cultural and religious values that, were overlapping (see Saldarini (1994:84; Ukpong 2002a:29). The Pharisees and other religious leaders defended the cultural and traditional values as heritage from their ancestors (Mt 15:1-3), while Matthew wanted to innovate these values with his new revelation of the fulfilment of prophecies in Christ Jesus (Mt 5:17-20; 12:1-8). This indeed, indicates to the reader the seriousness of the crisis the Jewish society found itself in.

The approach to this study finds a wide scope of application within the Banyamulenge community that went through a similar experience with the coming of the new religion (Christianity) in the early 1950s. Differences developed between the early Banyamulenge believers and the rest of the community regarding the community's old traditions and the new way of Christian living which was being introduced.

\section{BACKGROUND OF MATTHEW'S GOSPEL}

\subsection{Political setting and economic exploitation}

The book of Matthew was written between CE 85 and CE 95 in Antioch or in cities of Galilee (see Tenney 1982; cf Duling \& Perrin 1994:329-333; Overman 1996:16-19; Sim 1998:31-40). Matthew was a tax collector who converted to

\footnotetext{
${ }^{2}$ Banyamulenge people are Congolese of Tutsis origins from Rwanda, Burundi, but the community integrated also other Congolese tribes, which are not necessarily of Tutsi origin (see Mutambo 1997:41; Rukundwa 2004).

${ }^{3}$ Matthean community (Overman 1990; 1996) is defined and used in this study as a group of people, mostly Christian, characterised by common values and feeling of belonging to one another around Jesus' teaching as it is found in Matthew.

${ }^{4}$ Formative Judaism (Overman 1990; 1996) is described as an institution of Jewish religious leaders during the time of Jesus' earthly ministry and which lasted throughout the destruction of the Temple in the CE 70 period. The term "emphasizes the fluid nature of Judaism in this period, as well as the fact that for some time Judaism was in the process of becoming, that is, of consolidating, organizing, and obtaining a structure to ensure its existence" (Overman 1990:35).
} 
Jesus' teaching (Mt 10:3). As a civil servant in Palestine under the Roman occupation, he, like his contemporaries, yearned for a saviour, a liberator and a king of their own. The Romans exercised control over the land, the cities, and the entire economy. Carter (2001:9-10) says "with control of primary resources of land and its production" the Roman colonisers exercised their political influence, which helped them to exploit the country. Through its military force, it made all people to comply with payment of tributes and taxes (Mt 17:24-27; 22:15-22). At the same time, the Roman Empire used the elite class in the land to suppress and exploit the ordinary people.

In fact according to Carter (2001) the Roman imperial system was dictatorial and "a very small group of perhaps 2 percent of the population, ruled vast areas of territory through a small bureaucracy in alliance with provincial elites" (Carter 2001:10). The elite class comprised mainly the rich, bureaucrats, military leaders, and religious officials, as is the case in many societies today. The elite is always a minority group. As Tenney explains: "Both in Judaism and in the pagan world there was a wealthy aristocracy. In Judaism it was a religious group, consisting chiefly of the families of the priesthood and the leading rabbis" (Tenney 1982:47). Tension, revolts and violence marked the period. Through his passionate explanation, Klausner narrates how violence also spread throughout the land:

The unending succession of war, revolt and destruction also undermined relatively Judean economy, and reduced many of the country's inhabitants to poverty ... [L]ife and property became increasingly insecure; each day further swelled the ranks of the unemployed and the rebellious; and the country was driven to the brink of economic ruin.

(Klausner 1977:197-198)

Klausner (1977:194-195), Barbour (1988:26), Overman (1990:197-198), Stark (1991:197-198) concede that the regions of Judea and Syria were not only plagued by civil disturbances, but also by natural disasters, such as earthquakes, drought, famine and the outbreak of disease, all imposing misery on the populations. The poor were numerous and their condition pitiful (see Tenney 1982:49).

From what is described here above, it is clear that Matthew's sociopolitical context may have largely influenced and shaped his Gospel, and both Christianity and Judaism "developed within this colonial context of the Roman empire" (Overman 1996:7). 


\subsubsection{Cultural and religious setting}

Three major religious categories, namely Judaism, the Roman gods (Tenney 1982:65-120) and Christianity influenced Matthew's context and need to be considered. Culture and religion were distinct, but inseparable. According to Carter (2001:20-34), the Roman emperors were strongly attached to their gods. "Religious rituals and theological words were used by emperors and their officials, as well as by loyal supporters in Rome and in provinces to evoke 'a picture of relationship between the emperor and the gods." It is also known that the emperors made gods and goddesses (such as Minerva, Jupiter, Zeus), their protectors, sources of power and derived the will to rule from them. Temples were also dedicated to these gods.

On the other hand, the Matthean community and the formative Judaism (Overman 1990:3) were two of the movements emerging in the period between the two Jewish revolts, both of which were attempting to define, consolidate and give direction to their divided society affected by the Roman rule. Overman talks about "The Paradosis of the Fathers" (1990:62-67). It shows that both Judaism and Christianity shared traditional roots and the rivalry between them had been to gain control of the audience by traditionalising and legitimising their movements (Mt 15:1-9). These two movements shared the same background and thus had much in common. Overman (1996:19-26) defines their crisis in a manner that categorises it in terms of five points:

- "Leadership and cultural vacuum": the destruction of the temple disarrayed the community and provoked numerous contentions between various groups. Matthew viewed the Pharisees and scribes as rivals and threats to his community's "safety and the way of life" (1966:19).

- Crisis pertaining to the law and legal interpretation: "This is where Matthew defines most of the differences and disputes between these two groups" (1996:23).

- Issues pertaining to community order and structure: "Issues of discipline, community structure and authority, and instructions for church liturgy and worship are examples of the order that Matthew sought to supply for the group" (1996:21).

- Community identity crisis: "The turmoil and uncertainty that punctuated Matthew's world understandably provoked doubts and questions about 'who are we?' and 'where are we headed?' More than any other section of the Gospel, the Sermon speaks to the issue of Matthean identity" (1996:23).

- The crisis about the future of the community: 
Such angst was surely prompted by the prospect of the group's marginalisation, if not disappearance. What would happen to them and when, if ever, would things they had heard of and believed for too long, come to pass? Matthew argues that his community is in complete continuity with the history and eschatological drama of Israel, that which had happened to the great heroes of Israel, and the faithful people of Israel, is happening and will happen to Matthew's church (1996:23).

Following the destruction of the Temple and Jerusalem, the society is actually falling apart (Mt 12:25-26), and both formative Judaism and the Matthean community are making efforts to save it from a total collapse. But in so doing, each movement tries to prove itself by offering its best to the society. However, things were not all that smooth within the formative Judaism movement. Tensions and controversies about the theological formation and doctrine of the movement, reigned. The Sadducees for example rejected the traditions which the Pharisees claimed they had received from their ancestors and it became a bone of contention between the two factions. The Sadducees accepted only those laws written down in the Law of Moses (Mt 22:23-34), whereas the traditions of the Pharisees were not written down (Overman 1990:64), but handed down by ancestors. This tradition is also explained by Paul, a former Pharisee, in his letter to the Galatians (1:4).

For Matthew, the usage of Old Testament citations is not aimed at clarifying "'historical events' in the life of Jesus," but he is trying to stress his view that "these citations emphasize the Matthean community's claim to the very traditions formative Judaism was lifting up and claiming as its own." Interestingly, "Matthew's claim that these traditions and promises are fulfilled exclusively in the person and action of Jesus of Nazareth would provoke certain tension and struggle between these two movements" (Overman 1990:73-76). At this point, Saldarini also affirms that the Matthean community is still as Jewish as the rest of the other movements "though sectarian and deviant". The Matthean community has "deviated from the majority position through its devotion to Jesus as a risen apocalyptic figure who is the divinely sent emissary." He therefore seeks "to reform Jewish society and influence the way it will live and interpret the will of God" (Saldarini 1994:122).

Overman (1990:86-100) argues that the Sermon on the Mountain (Mt 5-7) contains the order of a community-forming structure. This structure is based on the law (Mt 5:17-20), righteousness (6:1-7:1-26) and order (5:2148). Issues of the law became a focal point in a conflict between Mathew and his opponents, because the law contained instruction material for every aspect of the community. Thus, stories and Old Testament citations confirm 
that Jesus and his followers were doers and not breakers of the law, as their opponents claimed.

Weakened by the suffering under the yoke of the Roman occupation, Jewish society became fragmented and cultural and religious common heritage became a source of division. For the sake of the survival of his community, Matthew worked hard to develop programmes, roles and leadership within his group and "articulated a defence of their position regarding Jewish law, future of God's people, and Jewish leadership in their setting. These procedures and developments served the purpose of instructing and defending the community"(Overman 1990:72). Saldarini (1994:112) also concurs with Overman that Matthew was busy recruiting members and developing a "coherent worldview and beliefs systems" to sustain his community. As a response to the imperial rule, Matthew, according to Carter (2001:57), also challenged the Romans by presenting Jesus as the King and the true agent of God's sovereignty (Carter 2001:57).

The Matthean community was in fact fighting for its survival and placing itself above all other movements and beliefs that could distract the message of the kingdom at hand. The attribution of the highest honours and citations from the Old Testament leave no doubt that Jesus had to continually face opposition from those who felt threatened by his emerging status (Rukundwa 2003:63).

\section{MEANING OF HONOUR AND SHAME ${ }^{5}$}

Extensive writings and research on honour and shame that were, undertaken from an anthropological and biblical point of view, have been produced by Malina \& Neyrey (1988), Malina (1993a; 1993b, 1996), Pilch \& Malina (1993), Chance (1994), Kressel (1994), Neyrey (1994; 1998), Plevnik (1998). Honour and shame are opposites and cannot complement each other, the one only existing in the absence of the other. In Malina's investigations of Mediterranean cultures, he identifies three boundary makers, namely "power, gender status and 'religion"” (1993a: 30). He describes honour as "socially proper attitudes and behavior in the area where the three lines of power, gender status and religion intersect" (1993a: 31). Elser (1994:25) defines honour as "the perception someone has of his or her own worth and an appreciation of how he or she is related by a relevant social group." For Plevnik (1998:106-107) honour "is a claim to worth that is publicly acknowledged." Neyrey (1998:32) defines honour as "the reputation, worth,

\footnotetext{
${ }^{5}$ Honour is defined as "a claim to worth along with the social acknowledgement of worth" (Malina 1993a:31); while shame is defined as a "claim to worth that is publicly denied and repudiated" (Plevnik 1994:107).
} 
and value which individuals enjoy in the eyes of the public." Shame on the other hand is "a claim to worth that is publicly denied and repudiated (Plevnik 1994:107). Neyrey (1998:30) gives a simple definition to shame as being "the reverse of honor".

According to Malina (1993:33; cf Neyrey, 1998:15) honour can be acquired through achieved or ascribed means. Neyrey (1998:16) postulates that ascribed honour "refers to the granting of respect and given to a person from members of the two basic institutions of antiquity, namely: family/kinship or state/politics". These may include birth rites; boys being favoured to girls in societies, and first-born boys being made heirs of families' responsibility, while achieved honour is secured through one's own efforts, merits and through competitions and wealth. For Malina, "it is the socially recognized claim to worth that a person acquires by excelling over others in the social interaction" (Malina 1993a: 34). For Esler (1994:27) "acquired honor is the socially recognised claim to worth which a person earns by excelling over others in various forms of social interaction." Neyrey adds that achieved honour "refers to the reputation and fame an individual earns by his own merits" (Neyrey 1998:16).

\subsection{Usage of honour}

Neyrey is rather sensitive to the dangers associated with honour, success or greatness (Mt 18:1-5; cf Mk 9:33-37; Lk 9:46-48). Neyrey considers fours things that would explain why the ancient cultures were so competitive, aggressive, envious and defensive in riposte, which can be summarised as follows: (i) Love of honour, which pervaded Greece, Rome and Judea. For love of honour, people became too ambitious through excellence or vicious means, rivalry, war and violence. (ii) Perception that all goods, including honour, exist in limited supply. (iii) Phenomenon of envy resulting from the success of others. (iv) The general competitive nature of man in society (Neyrey 1998:16-28). The Bible contains many examples of dangerous attitudes which resulted in competition and envy: the case of Cain and Abel (Gn 4:1-12), Dinah's rape (Gn 34), Joseph and his brothers (Gn 37), Joseph and Potiphar's wife (Gn 39), children of Israel in Egypt (Ex 1:8-2:10), Herod and Jesus (Mt 2:1-14), Pharisees and Jesus (Mt 12:14).

As far as symbols of honour are concerned, both Neyrey (1998:21-22) and Malina (1993a: 38-39) talk of "blood and name and the collective honor." Social and family reputation is based on how members of the community are perceived as "living according to the code of expected social behavior of village and neighborhood"(Neyrey 1998:21). Consequently, members of that community "share in its reputation: all rejoice in its honor and all share in its 
shame. Honor, then, is symbolized by family blood" (Neyrey 1998:21). A connection of family and names makes identity valuable within a given society (Mt 1:20; 4:21; 16:17).

What about gender and honour usage? Neyrey (1989:29-30; cf Chance 1994:139-149) dealt with how these concepts were used. Roles were determined according to gender and the ancient world was fundamentally gender divided. Men were to show that they were courageous and brave, able to show the "family's worth and standing" (Neyery 1998:29). Females, on the other hand were expected to be submissive and obedient. Neyrey continues by stating that "their worth was nearly equated with sexual exclusivity, which they must guard along with the other valuables of the family." For Chance, female honour was linked to marriage and the highest value was placed on virginity (Chance 1994:140). Socially, women enjoyed no status; often being classified in the same category together with children and/or the marginalised (Wire 1991:95).

This is also typical of the Banyamulenge culture where a man had to prove his courage by protecting his livestock in the fields from wild and animals. He had to prepare the farm so that his family would not suffer starvation. He should also strive to make a social contribution towards the community, such as helping the poor. He then would be called imfura (a man of integrity). For a Banyamulenge woman, her obedience and submission signified how much love she had for her husband. Love must be shown in her commitment to her family-in-law and to her own home and the community. She too could then be called imfurakazi (a woman of integrity).

\subsection{Aspect of shame}

For Neyrey (1998:30-33), there are three aspects to shame: positive, negative, and gender stereotype. Firstly, shame has a positive meaning when it is in the context of "a shame-regarding person". It helps a person to have knowledge of what opinion his audience, peers or group holds about him or her. This kind of shame could actually remedy behaviour as a consequence of someone's fear for group's censure on his or her behaviour. In this sense, shame would be "a virtue in a world where honor is a pivotal value" (Neyrey 1998:30).

Secondly, when shame refers to "the loss of respect and regard by some public", it has a very negative meaning. It can also mean "the loss of face, disgrace, and dishonor" (Neyrey 1998:30-31). It can therefore also mean the loss of love, confidence and trust ( $\operatorname{Pr} 19: 26)$. Matthew challenges this assertion and makes it clear that even when one is not seen by men, God is 
watching him or her and would bring to light all things done in the light and the dark on the last day (Mt 22:11-15; 24:51; 25:12, 26, 41, 46).

Thirdly, shame can dignify females in their household. Neyrey (1998:32) says "anthropologists note the following association: honor: male; shame: female ... Here we call attention to the broad social expectation that males will compete for honor in the public arena in contrast to females, who are expected primarily to be defensive of the family honor by virtue of their chastity." In a sense, females are expected to display some "shyness, not concern for prestige, deference, not concern for precedence, submission not aggressiveness; timidity, not daring; and restraint, not boldness". In so doing, "they are judged positively in the court of reputation when they live up to the social expectations encoded in the gender stereotype" (Neyrey 1998:32).

Aspects of honour and shame form a central point in the Banyamulenge culture. Honour is regarded as the highest value a community could strive for. Let me quote some examples in this regard: My grandmother, Maria Kanenge, was a mid-wife. She had no formal schooling in this profession, but solely relied on her natural talent. Everyone in the surrounding villages and localities spoke highly of her and respected her. Her profession earned her and the family a good name and honour. Eloquence and the ability to deliver good speeches were typical areas of competition in male circles. Even when the church replaced the old tradition, eloquence would still be judged through sermons: "that pastor is a good preacher, he is eloquent," people would say. Wealth (ubutunzi), family integrity (ubufura), courage and being valiant (ubutwari) earned a lot of honour and a good reputation in the community.

For Banyamulenge women, shame (isoni) had a double meaning. Isoni could be synonymous with obedience. For instance, women were not supposed to call their husbands' names in public nor that of their in-laws. Women were not supposed to sit with men in public. The sharing of meals was another example, and is still adhered to in villages: women are not supposed to share meals with their husbands. Banyamulenge men were to show the same kind of obedience, isoni, especially towards their in-laws. They were not supposed to eat from the same table, or pass a night in the same house.

Isoni also meant obedience for men. For instance, in case of a dispute between two persons, the matter was brought to a council of elders. When the matter had been settled, the party that felt its rights or justice had been reduced at the expense of the other party, would say ntinye abagabo or ngize isoni za bagabo, (I obey/ respect the decision of elders). At the same time, Isoni also has a negative meaning when associated with shameful acts, which 
went against cultural values and norms, such as disrespectful behaviour towards elders and family. In the case of domestic conflict, it would be shameful for a man to be beaten or to be insulted by his wife. Similarly, it would be shameful for a man to be beaten or insulted in public, in the presence of women and children. It was also considered as shameful for a man to eat with women or members of other neighbouring communities.

\section{ASPECT OF HONOUR AND SHAME IN SELECTED PASSAGES AND ITS APPLICATION IN THE BANYAMULENGE COMMUNITY}

\subsection{Whose Son is this: Genealogy of Jesus and Gentile women (1:1- 2:1-18)}

Today, in a world of globalisation, genealogy seems to be outdated, yet the best way to understand one's identity, is to know one's past. In Jewish culture, genealogies serve as "social maps, sources for historical information about one's ancestors. They tell who belongs socially with whom and define standing in the community (Malina and Rohrbaugh 1992:25). According to Overman (1996:29-30), in his opening chapter, "Matthew addresses profound questions about Jesus' identity and heritage, origin and place within the history of Israel."

According to Garland (1985:14-16), Matthew's introduction links Jesus to two main promises of God to Israel: (ii) "son of David" reminded Israel of its kingdom promise (2 Sm 7:12; 1 Chr 17:11-14; Is 11:1-5) "to raise up David's offspring and to establish the kingdom of his throne forever" (Garland 1985:15); (ii) "son of Abraham" reminded Israel of its blessing promise (Gn $12: 21 ; 22: 18)$ "that by his seed all the nations of the earth shall gain blessing" (Garland 1985:16). Mark does not deal with the issue of genealogy (1:1-2; $1: 12)$, but it is taken up by Luke (3:23-37) when he traced Jesus' origin, not only to Abraham, but also to Adam and to God Himself (Gundry 1994:14). Malina and Rohrbaugh state: "Genealogies encoded the information people needed to know in order to place themselves and others properly in the social order. A genealogy is thus a guide for social interaction" (Malina \& Rohrbaugh 1992:24). Main characteristics that already appear in the opening chapters one and two are: (i) blood and names linked to Jewish ancestry and Gentile women; (ii) Immanuel and Saviour; (iii) both political animosity and alliance; (iv) citations from the Old Testament. The main focus of Matthew is to make Jesus not equal to his "ancestors" but to depict him as the one who overshadows them (Garland 1985:16). 
In the Banyamulenge community and many other patriarchal customs, sons are born to fathers. Although Joseph had no sexual contact with Mary (Mt 1:25), Jesus had to follow the lineage of his earthly "adoptive" father. He became a descendant of Abraham and David. According to Banyamulenge culture, a son is always associated with his father and not with his mother. Association of a son to his mother is regarded as shameful and disrespectful. However, the son plays a role in legitimising and honouring his mother in the family. "The birth of a son assured her of security and provided status recognition in her husband's family (Malina and Rohrbaugh 1992:30).

In actual fact, the birth of Jesus was reassuring Israel of God's renewal of his saving grace and power. God's mission at a time like this was to restore His honour and presence to Israel and to take away its shame. Thus, Immanuel is born (Is 7:10-16; 9:1-7; Mt 1:22-23). Wire (1991:101) asserts that Matthew "insists that Jesus does not lack a messianic lineage and name, nor a messianic place and time of birth." This is what is termed by Neyrey as ascribed honour. Again, "it was common for the ancients to praise a person in terms of both generation and geography" (Neyrey 1998:37, 94-97; see Moyise 2001:41).

The birth announcement of Jesus came to Joseph in a dream and prophecy (Mt 1:18-24; 2: 13-14, 19-21), as it is also revealed to Herod (Mt 2:56). According to Overman (1996:37) "Dreams were a standard way in which the gods spoke to people in antiquity. The receiver of the dreams, or seer, was considered a particularly anointed, spiritual, or powerful person. The one who could determine what the future augured was one who could go where only angels and other anointed ones dared to tread." In Banyamulenge culture too there were seers, called the abaragu. People would go to them to enquire about their health, families, livestock, et cetera. When people were converted to the new religion, Christianity offered them prophecy, dreams and visions.

The names ascribed to the child are significant insofar as they portray who he is. In Banyamulenge tradition, they say "izina niwe muntu", which literally means the name is the man, or the name you give your son portrays his character. As a result, the Banyamulenge take great care in the naming of their children. The naming of Jesus is not taken for granted here. Overman (1996:36) notes that the interpretation and meaning Matthew gives to the naming of the child, "highlights the mission the community believed Jesus was called to undertake." Saldarini (1994:171) also says that by introducing "Jesus as Messiah, son of David, and son of Abraham in the first sentence of the gospel, the author taps the core of his Jewish tradition." His name is Immanuel, God and King not only for us, but also with us. In a sense, this name has soteriological, political and eschatological meaning. Israel longed 
and waited impatiently for the Messiah who would restore them in the covenant with God. He will save them from their sins. At the same time in a political context, Jewish society under the Roman regime was on the verge of collapse and indeed, a political figure of their own, a "Saviour", was desperately needed. Jesus' ascribed honour is not accidental or circumstantial, but foreordained (Overman 1990:75).

Brueggemann does not take for granted the role the angel Gabriel played in Luke. According to him "the birth announcement is the assertion that God was powerfully at work for those who cannot fight their own battles" (Brueggemann 2002:42). During the reign of the Roman Empire when Jesus was born, no one could openly challenge the regime. It was an age where the sword, oppression, fear and danger reigned. Yet, Scriptures are fulfilled and are quoted to the King Herod (Mt 2:3-6; cf Is 7:14-15; 9:1-8). The visit of the Magi also carries a double meaning: one is that they are gentiles. (see Saldarini 1994:69-70), the second is political (Overman 1996:43).

Going back to the Lukan reference, Ukpong (2002b:68-67) argues that the birth of Jesus in Palestine was a "political threat to the oppressive Roman government" and God has come to intervene on behalf of the poor and the oppressed, the marginalised and all unjustly treated people (Lk 4:18-19; cf Is $61: 1-4)$. Suffice to say that throughout generations this message and mission continue to bring hope to the suffering world. When the politics of the CongoZaire turned against the Banyamulenge (Rukundwa 2003:37-41), they sought refuge in God. Prayer became their only consolation in the hope that somehow, God would intervene on their behalf and would argue their case.

The presence of Gentile women in the Jewish cultural context is a peculiar phenomenon still surrounding the meaning of the birth of the Immanuel. Both Mark and John do not mention anything about the genealogy of Jesus. And Luke who does (3:23-37) does so in a Jewish way, which is a patriarchal tradition. In his genealogy Luke does not mention women, not even the mother of Jesus. To the Banyamulenge this is not surprising, because even in their culture too, women are not listed in a genealogy (see Rukundwa 2003:17-19). It is however interesting to note the contrast that exists between the Matthean and Lukan announcements of the birth message and the place of women. Luke uses women (1:26-56), while Matthew uses Joseph (1:1825). Luke might have been influenced by the fact that in the Greco-Roman world, women played an important role as "interpreters and divine channels" and many of their "cults of this period focused on goddesses" (Overman 1996:39). On the other side of the Mediterranean, the Banyamulenge worshipped Ryangombe, a goddess or a mediator between abantu (people) and Imana (God). Generally, women were never given a prominent place in 
narrative stories by Matthew. But in three places they are mentioned in a very peculiar way: at the birth of Jesus (1:1-17), at the demonstration of faith (9:2022; 15:21-28; cf Mk 7:24-30 and Lk 8:43-48) and on the resurrection day (28:1-16; cf Mk 16:1-8; Lk 24:1-12 and Jn 20:18).

But what is surprising is that Matthew introduces in his account Gentile women, associated with an unpleasant reputation or marital irregularities (see Garland 1985:17-19; France 1985:73; cf Overman 1996:34-35). Neyrey's argument on gender and honour says, "women belong to the private world" (Neyrey 1998:29), and do play a very low-key role in public. Nevertheless, in the birth story, four Gentile women (Mt 1:1-18) appear in a very significant way. They proved not only capable of keeping alive the lineage in Jewish society, but also of setting an incomparable example of determination, commitment, love and faith. They are Tamar (Gn 38), Rahab (Jos 2; 6), Ruth (Rt 1- 4) and Bathsheba (2 Sm 11). These women all had one thing in common: they were associated with a bad reputation (see Corley 1993:150152). However, these women were great and were recognised because of their "achieved honour" in saving Israel and for the role they played in the continuation of the royal line of David (Overman 1996:35). Moreover, they are also portrayed as heroines ushering a Gentile community into Abraham's and Jacob's descendants and blessing (Gn 12:1-3; 35:10-11).

As far as Mary is concerned, not much is said about her, except for Joseph's plan to spare her disgrace in public (Mt 1:19), but he is prepared to terminate the relationship, because of her premarital pregnancy, which the Banyamulenge would call inda yindaro. It is also noteworthy that Mary warned the angel in advance that she was a "virgin" (cf Lk 1:34), which is characteristic of her faithfulness to her culture, as it was for Banyamulenge girls too.

Let us also consider the faith of the Canaanite woman (Mt 15:21-28; see O'Day 2001:115-125; cf Mk 7:24-30), and the reference of the Johannine story of the Samaritan woman (Jn 4:1-42; cf Maccini 1994:35-46) as well as the Banyamulenge woman Kibihira. Their role in their respective societies is beyond imagination, their faith, courage and insistence, making them think and act far ahead of their time. This is what the Banyamulenge expression would call umugore magabo, literally meaning a woman-man, that is a woman of courage and power. Their faith earned them honour in spite of their shame - shyness culture (Neyrey 1998:31-32; cf Plevnik 1994:107). Moreover, they also informed us of how they are not only the carriers of a lineage, but also the carriers of faith through generations, raised from humility and ashes to glory. Wire (1991:106) argues that even though women had neither a role nor status in society, in Matthew though "the women's role of deficiency or 
dependence is not overcome but is used to challenge others to meet their needs and at the same time to learn humility and faith from them." Their commitment, love and faith have contributed to usher the whole humanity into God's saving mission. To summarise then, Matthew has recorded two entries of Gentile women, and for a Banyamulenge audience, Madam Kibihira might very well have been the third such entry. Madam Kibihira's faith and openness to the Gospel are remarkable. Although these women are associated with a bad reputation, shame and disgrace, through their faith they achieved honour in their own time and through generations.

In the Banyamulenge community, the application of Jesus' genealogy has three relevant dimensions:

- Patriarchal dimension. A son is born to the father who belongs to a family. He is the son of ...(mwene naka ...). Sons are heirs of wealth, power, blessing and family. They are the carriers of their fathers' names. He was presented as the true mediator between man and God: a Son to his Father. To this day, Genealogy is a means of family identity.

- Names of the son and honours attributed to him. The son was to save his people and through him came the fulfilment of God's promises to his people. A family is respected through the sons born to it. Jesus' introduction to the community came as a spiritual, social and political saving figure.

- $\quad$ Gentile women being part of God's plan for salvation. God honours the dishonoured and strengthens the weak. Madam Kibihira, like any other Banyamulenge woman, was not influential in the community. As her predecessors mentioned in the narrative stories, Kibihira was associated with a bad reputation: she hanged herself as a result of the persecution she suffered for the sake of her faith. Her death drew sharp theological debate, with some views supporting her as martyr of the Gospel, while others simply maintained she was wrong. Be that as it may, by her faith she became the first woman ever in Banyamulenge history to respond to the Gospel and to pay the price (her own life), for the sake of that Gospel. She accepted to carry all the shame of her culture and was brave enough to carry her cross and follow her Master (Mt 10:34-39; cf. Mk 8:34-38; Lk 12:51-53, 14:25-27).

\subsection{The message of the kingdom and the life of the community (5-7)}

His opponents still with him, Matthew's battle continues, a battle he has to win. Jesus' ministry is enriched with both heavenly and earthly ascribed honors by John the Baptist (Mt 3:11; cf Mk 1:7; Jn 1:26-27) and by God (Mt 
3:16; cf Mk 1:11; Lk 3:22). According to Malina (1993b:2) honour is neither a function nor a social role, but "honor is a value," of which Matthew is forging the way ahead to persuade his audience that Jesus was their Saviour today and tomorrow. God is pleased with him and the world must obey him. Neyrey (1998:164) comments:

\begin{abstract}
Matthew presents Jesus reforming the fundamental value of his culture, namely, honor. His reform consists not only in refining and correcting the Torah of Israel, but also in engaging the values and consequent social structures of his social world. Jesus did not overthrow the honor code as such, but rather redefined what constitutes honor in his eyes and how his disciples should play the game.
\end{abstract}

It has to be understood that in the period from Jesus' birth until his ministry, no change for the better occurred in the socio-political situation. "Deplorable social conditions and poverty occurred in greater intensity during the period of the monarchy, when the social stratification between the poor and rich, between the oppressed and the rulers widened. The prophetic critique was directed against this development and declared God to be the protector of the poor" (Gnilka 1997:175). In chapters 5, 6 and 7 Matthew's main concern is to set standards and to define values for his community. Matthew has chosen and arranged extensive teachings, which might be seen as paramount evidence of the crisis in the community and its surroundings. He is set to instruct his audience on how to live as a new community of followers of Jesus (see Saldarini 1994:98).

Indeed, the practice of setting measures for community discipline was not new to Jewish community. Overman (1990:48-50) states "within the fluid period which gave birth to formative Judaism," different movements competed for influence and control. "It is accurate to claim, however, that a decisive stage in the process of communal self-definition is reached when a community sets criteria for exclusion." It is therefore not surprising that Matthew used a banning and expelling connotation to encourage and admonish his audience, which might have gone through a similar experience.

Disciplinary measures in the Banyamulenge traditional community were strict and orderly. Members who did not follow cultural patterns were sanctioned by paying fines (iciru) after having gone through counselling by the elders. In the event of a person not changing, he would be expelled (gucibga) from the family. The early believers were excommunicated from the rest of the community. As the church gained ground in the community, the same 
disciplinary measures were used in order to safeguard the new community's (church) values.

\subsection{The kingdom today and tomorrow}

Examining the eight beatitudes (5:3-12) it could be said of them that they are messages of comfort, encouragement and perseverance. Having taken cognisance of the socio-political context within which the Matthean community developed, it is clear that his=Matthew's? audience was in a way questioning him or rather reminding him of the kingdom establishment in the here and the now. The Matthean audience's hardship and pressure seemed to have been unbearable. As a result of what they believed in, the community was going through marginalisation, humiliation, exclusion, disgrace and shame vis à vis their neighbours. In an unexpected way, Matthew's Sermon on the Mountain turns the shame to honour and the disgrace to glory: "honoring the dishonored" (Neyrey 1898:164).

The beatitudes or makarisms, undo the shame and humility the Matthean community was enduring for the sake of the new kingdom model, and the community thereby receives respect, and the promise of the Master in the here and the now and in the kingdom to come. The beatitudes can to some extent be divided into groups. The first category concerns itself with the general human situation of poverty, hunger, suffering, humility and meekness and reconciliation (5:3-9). The others deal with endurance in the face of persecution of community members (5:10-12). Matthew's message with regard to the persecution of his community (cf Lk 6:22-23) requires particular attention, as these verses are crucial. "Happy are you when people insult you and persecute you and tell all kinds of evil lies against you because you are my followers. Be happy and glad, for a great reward is kept for you in heaven. This is how the prophets who lived before you were persecuted."

The message thus is that Jesus "revalues what has been disvalued; he honors what has been shamed" (Neyrey 1998:167) for the sake of the heavenly kingdom. Jesus addressed those who have suffered ban, insults, exclusion and persecution because they are his followers. Yet, a conjunction of this message and the Markan reference (8:31-38) is rather decisive. Mark makes it clear that honour is not only ascribed, but also achieved. Members of the community have a part to play in order to gain worth. Referring to the same achievement, Paul in his charismatic testimony, counted all his profit as a loss for Christ's sake (Phlp 3:1-11).

The Sermon on the Mountain, especially its last beatitudes, strongly applies to the persecution of the first believers (the church) in the Banyamulenge community. It is interesting to note how the degree of faith of 
those who follow Jesus to the point of risking their lives, can be judged. Reading the Sermon on the Mountain, one gets the impression that Jesus is talking to a desperate audience without other options at hand. This is also true of Madam Kibihira, Mr. Kajabika, Mr. Mwungura and the young man Karikofi who in 1945 converted to Christianity. The threat they experienced was not political, but cultural and traditional, coming from within their families and community. Shame befell their families and they were unable to withstand the disgrace that their sons and daughter had brought upon them. Not only did the first Banyamulenge believers lose honour in their families, but also amongst their peers. They were treated as people with no value. Madam Kibihira got divorced, was rejected and expelled by her ex-husband and her own parents' family because of Christ. With no other place to go, and then she hanged herself as a quick way of leaving this world of pain and persecution to be with her Lord (Phlp 1:22), although Christian tradition does not recommend suicide.

Mister Mwungura suffered the shame of divorce from his wife and Kajabika paid the price for his faith, as he could not find a wife to marry in his community. Both of them had to get non-Banyamulenge, but Christian wives. The young man Karikofi had to flee from his family for many months after his father wanted to kill him. His father threw a machete at his neck, but it fell on his cheek (cf Mt 10:34-39; Lk 21:53). It has to be understood that families were acting in this manner in order to save face in their community. They did not want to be associated with ishano ryaguye (curse or disgrace that befell them). These valiant people of faith gave up all their comforts, accepted public shame, and carried their own crosses in pursuit of the priorities of the kingdom (cf Mk 8:34-38; Lk 14:25-27) for today and tomorrow. Six years later, the entire community started to follow the God of Kibihira, Mwungura and Kajabika. Then, they became the most admired and respected people at last. The people who are declared honourable by Jesus are those who "had suffered a total collapse of social worth on Jesus' behalf" (Neyrey 1998:187). Referring to enduring persecution, John in Revelation comforts his companions by staying "I am your partner in patiently enduring the suffering that comes to those who belong to his Kingdom" (1:9).

\subsection{Community rules into the kingdom and "Calling Off the Honor Game" (Neyrey 1998:190)}

The next part of the Sermon (5:13-7:29) deals with how the Matthean community was to live and behave within their own community and in the world. "The development of social, community values and ethics also provided guidance and meaning for individuals." These requirements are arranged from 
"communal life, the behavior of its members, the disciplining of errant members, and the community's response to those outside the community and in the civil realm, relationship, worship ... " (Overman 1990:90-91, 100). Jesus himself was the first to set the example and then others were to follow. John quotes him as saying: "My food is to obey the will of the one who sent me (Jn 4:34), while his mother Mary tells the servants at the wedding ceremony in Cana to "do whatever he tells you to do (Jn 2:5). Concluding the sermon Jesus turns to the crowd and tells them about the requirements of admission to the kingdom: "only those who do what my Father in heaven wants them to do" (Mt 7:21). For Overman, the Sermon on the Mountain can rightly be described as a constitution for the Matthean community (Overman 1996:104).

The Sermon outlines requirements of membership and for order within the community. Most of these rules are not new as such, but are reorganised, and reoriented from Jewish tradition and Law. Saldarini (1991:50-51) is convinced that Matthew brought "innovations" to the Jewish tradition to fit his audience and made Jesus a focal point of his message. Jesus told his audience that he did not come to abolish the Law, but to fulfil it (5:17). The innovations Saldarini is referring tot have to take place within Jewish tradition rather than the invention of new ones.

Unlike Matthew, missionaries to the Banyamulenge community had no time for the community's cultural values and meanings. They discarded everything cultural as bad and did not see the value of either innovating or changing existing societal rules/values for the good (Rukundwa 2003:29-31). Matthew however sensed that he had to solidify his community and open-up the door for the marginalised and for Gentiles, something his opponents would criticisise. But that was the rule of the kingdom.

The Sermon on the Mountain therefore, provides values, priorities and measures for discipline of the Matthean community, which are "mimetic reiteration of the priorities and judgments of the kingdom, which is in heaven," (Overman 1996:105). The comparison between the Matthean community and the kingdom of heaven is well summarised in the Lord's Prayer that "may your Kingdom come; may your will be done on earth as it is in heaven" (Mt 6:9-10). What the author is trying to explain is that heavenly ways are not necessary earthly ways. How then should riposte, revenge, justice and love be interpreted in the community (5:38-48)? Overman's opinion with regard to these verses is that "Matthew unveils what he believes to be the hermeneutical key to all the laws and the prophets" (Overman 1996:82). It is obvious that this attitude changed minds and disappointed many who might have been seeking support for their social issues in a traditional way. 
According to Wink (1992:102-125), the interpretation of sayings found in 5:38-42 is that it does not signify cowardliness, but that it is a way of humiliating the oppressor. "A backhand slap was the usual way of admonishing inferiors. The only normal response would be cowering submission" (1992:105). The question that Wink then poses is why does Jesus "counsel these already humiliated people to turn the other cheek?" His answer is very interesting:

Because this action robs of the oppressor the power to humiliate. The person who turns the other cheek is saying, in effect, "Try again. Your first blow failed to achieve its intended effect. I deny you the power to humiliate me. I am a human being just like you ... You cannot demean me." Such a response would create enormous difficulties for the striker ... If he hits with a fist, he makes the other his equal, acknowledging him as a peer ... [I]n the world of honor and shaming, he has been rendered impotent to instill shame in a subordinate. He has been stripped of his power to dehumanize the other.

(Wink 1992:105-106)

As the church was taking shape in the Banyamulenge community, church rules and doctrines replaced the cultural and traditional values of people. Although it might not have been done in the best way, the missionaries wanted to see a radical change! One example was to encourage the eating of chicken, fish, goat, (goat for women) or eating together with strangers (neighbours), a meal served as a public confession of humility, courage and commitment to a change that had taken place (Rukundwa 2003:14-15; 83). But to the community these meals were like bitter herbs - or as westerns would say, a bitter pill.

Matthew (5 \& 19) deals with the code of family issues, especially focusing on marriage in the new community. Overman (1990 and 1996), Neyrey (1998) and Carter (2000) deal with the issue by using the Jewish prominent schools of thought, Shammai and Hillel. Matthew raised the issue of marriage and divorce, because it was such a serious problem in his time. As Tenney explains “... human life was cheap ... divorce was easy to obtain and was generally accepted in 'society"' (1982:58). But what happens beyond Matthew's culture? Three issues which are found in Banyamulenge practices remain crucial.

The marriage of a divorced man with an unmarried woman: It is true that women enjoyed no social status in Jewish and Greco-Roman cultural settings, which, as Carter (2000:378) puts it, "reflects dominant Jewish and 
Greco-Roman attitudes to women and divorce." But the case of Mwungura is an interesting one. His wife divorced him because he defiled his culture and tradition by being baptised. Families supported this divorce, because Mwungura dishonoured them. In this case, Pauline theology on marriage and divorce would permit Mwungura to remarry (1 Cor 7:1-24).

Restriction of polygamy and the cultural rights of widows: Apart from his reference to the story of creation (19:8), Matthew does not explicitly deal with this issue. The Pauline theology of marriage however deals with this issue, but also in a very strict and limited way, referring to the position of bishops (1 Tm 3:12); and that of widows in the community (1 Tm 5). The practice of the Banyamulenge, similar to the Jewish tradition, is to take care of a widow, the implication being that the widow is our widow, and she must produce offspring for our (brother's) family (Gn 38:1-9); this is so in the case of Ruth and Boaz (Rt 2-4). That was how an individual retained his or her honour in the community. In actual fact if one's widow did not have children, or had not been taken care of, it became shameful to her and her family-in-law. A serious challenge in the form of thousands of widows presents itself to the Great Lakes region and to many other war-torn countries in the world.

But another complicated issue arose in the community during the early 1970 's to 1980's. The church was plunged into theological crisis on marriage and divorce when a prophetess Mariam Kinyamarura developed her own teaching on the matter. Her argument was that if a young man and a young girl had intercourse, it should be considered as a consumed marriage. It was also to be applied to widows and unmarried men! The community saw many Christian homes broken up just because one of the partners had a sexual affair or illegally lived with someone else before he/she got married.

As we have seen earlier in the story of the dreams and visions at the birth of Jesus, seers were very important. A time was reached in the Banyamulenge community where some church leaders had no say or decisionmaking powers in their churches as directives had to come from the prophetess. Divisions and prophecies in churches were also a concern for Matthew too His community was to set an example as being light and salt (5:13-14); as good prophets (7:15-20); not judging others for any reason (7:1$5)$. The community was to be one in culture, mind and in spirit, because the Master does not bring division in his own kingdom (12:25). The confusion in prophecies and divisions that the church in the Banyamulenge community experienced during the early 1980's (Rukundwa 2003:43-52) was a real test to the application of kingdom models.

In 1980 many local churches left the Swedish Pentecostal church movement? (CEPAC) and joined the Assemblies of God (CADC). According 
to a letter written by Mudagiri, Rugabirwa \& Mwungura (1980) on behalf of the churches leaving CEPAC, the main accusations against its leadership were corruption, injustice, dictatorship, nepotism and tribalism. The frustrations of the Banyamulenge pastors were shared by many other pastors from other communities too. But the Banyamulenge people became vocal, because their socio-political survival depended on church leadership, especially after the death of the M P Hon Gisaro Muhoza. This struggle coincided with the conflict of the Groupement de Bijombo (Mutambo, 1997:86-93), a local politicoadministrative entity of the Banyamulenge community. It was contested for many years and the debate on social imbalances and different "cultural readings" re-surfaced again.

On the other hand, the churches within the Banyamulenge community were divided by Mariam's prophecies, in terms of which the move was considered as being political (icama) and sinful. For this reason, no one was to have been associated with it. Other denominations were sharply divided about whether to accept the new church, or to just excommunicate it. An agreement could not be reached. Churches that considered the prophecies to be true, distanced themselves, and prohibited all contact, including marriage, with people from the Assemblies of God (Buhungu 1992:50). In 1997 the national leadership of the Swedish Pentecostal church officially announced forgiveness in favour of the Assemblies of God (Mehne \& Kuye, 1997). But to this day some church members in the Swedish Pentecostal and Methodist churches, especially the followers of the prophetess Mariam, reject the decision.. By accepting the decision, would be to question the authority of the prophetess. Indeed, there has to be another journey for the church to revisit the meaning of the Cross of Christ in the life of the church today.

\section{GREAT COMMISSION}

The story of the resurrection relieved Matthew and his community of their shame. Again, the first announcement of the resurrection is by women, the weak (Mt 28:1-7, cf Mk 16:1-6; Lk 24:1-11 and John 20:1-2, 17) as it was at the birth (cf Lk 1:26-38)! Regardless of who the messenger was, the good news was He has, victoriously, risen (Mt 28:18; cf Rv 1:18). What remains to be done was to send missions to the nations. And in narratives the disciples were taught how to serve the crowd $(14: 19 ; 15: 36)$ where after they were sent to teach Israel (10:5-6) and to go to nations and make disciples (28:16-20). The message emerging from the cross was to be preached to all nations.

Secondly, there is an interesting dimension to the birth story and the Great commission, namely the omnipresence of Immanuel (Mt 1:21-23; 28:1820). Brueggemann explains it as follows: "the Godness of God does not 
consist in his power and sovereignty but in his obedient suffering for the sake of the world .... The call of God is to embrace the passion and suffering, to care for the weak, which God does all through biblical history" (Brueggemann 2002:9). This, that God is with us, is the message to the world.

The message of the Great Commission is given with a revolutionary mind, namely to change the existing world and to turn it into a model of the kingdom of heaven, to go and make disciples. Overman says, "This Matthean conclusion to the Gospel might provoke more members to take the rest of the world seriously. This mission gave Matthean Jews a chance to teach and enforce their view of the prevailing order, which they believed they received from Jesus" (1990:408). Whether one belongs to the Davidic or Roman and Gentile kingdoms, one is eligible and invited to enter and to be part of the new community of the kingdom. That is how the Banyamulenge community became part of it and started to share in all of its benefits 1950 years after its announcement.

\section{CONCLUSION}

Matthew provided a profound message of a divine intervention in a cultural context. The combination of Overman and Neyrey enriched the contextualisation of the message. On the other hand, Matthew's text, studied in a context of honour and shame, and the application thereof in the Banyamulenge community, are relevant.

The Matthean community and formative Judaism were two positions within the Jewish community that competed to save the face of their collapsing society. The Matthean position was to innovate the culture in order to suit his audience, which was mainly composed of disadvantaged and , marginalised people, as well as Gentiles. The church in the Banyamulenge community played the same role of bringing new meaning to life in the community. The place of Gentile women in Jesus' genealogy and accounts of the Canaanite woman, as well as the life story of Madam Kibihira prove God's salvific plan to the nations. Although these women are associated with a bad reputation, shame and disgrace, their faith achieved honour for them in their times and beyond for generations to come.

Jesus on the cross replaced all the animal sacrifices that served as ways of pleasing and maintaining fellowship with the gods in the Banyamulenge culture. Madam Kibihira, along with Kajabika and Mwungura's receptive spirits opened a door to the Great Commission's message for the Banyamulenge community 1950 years after Jesus' birth, death and resurrection. 


\section{Works consulted}

Avi-Yonah M \& Baras Z (eds) 1977. Society and religion in the second temple period. London: W H Allen.

Balch, L D (ed) 1991. Social history of the Matthean community: Cross-disciplinary approaches. Minneapolis, MN: Fortress Press.

Barbour Publishing Inc 1988. Josephus. Thrones of blood: A history of the times of Jesus $37 \mathrm{BC}$ to $A D 70$ ? Uhrichsville: Barbour Publishing Inc. (This book is a paraphrase of Whiston's translation, part The Antiquities of the Jews and part The Jewish War.)

Brueggemann, W 2002. The Bible makes sense. Rev ed. Louisville, KY: Westminster John Knox Press.

Buhungu, R M 1992. Implantation de la 37e CADZ et ses relations avec les autres communautés des Hauts-Plateaux du Sud-Kivu. Unpublished monographie de graduat en théologie, Université des Pays des Grands Lacs.

Carter, W 2000. Matthew and the margins: A socio-political and religious reading. Sheffield: Sheffield Academic Press.

Carter, W 2001. Matthew and empire: Initial explorations. Harrisburg, PA: Trinity Press International.

Chance, K J 1994. The anthropology of honor and shame: Culture, values, and practice. Semeia 68,139-149.

Corley, K E 1993. Private women, public meals: Social conflict in the synoptic tradition. Peabody, MA: Hendrickson Publishers.

Dietrich W \& Luz U (eds) 2002. The Bible in a world context: An experiment in contextual hermeneutics. Grand Rapids, MI: Eerdmans.

Duling, D C \& Perrin, N 1994. The New Testament: Proclamation and parenesis, myth and history. $3^{\text {rd }}$ edition. Fort Worth, TX: Harcourt Brace College Publishers.

Esler, P F 1994. The first Christians in their social worlds: Social-scientific approaches to the New Testament interpretation. London: Routledge.

France, R T 1985. Tyndale New Testament Commentaries: Matthew. Grand Rapids, MI: Eerdmans.

Garland, D E 1993. Reading Matthew: A literary and theological commentary on the first Gospel. London: SPCK.

Gnilka, J 1997. Jesus of Nazareth: Message and history. Peabody, MA: Hendrickson Publishers.

Good News Bible1994. $2^{\text {nd }}$ edition.

Gundry, R H 1994. Matthew: A commentary on his handbook for a mixed church under persecution. $2^{\text {nd }}$ edition. Grand Rapids, MI: Eerdmans.

Klausner, J 1977. The rise of Christianity, in Avi-Yonah, M \& Baras, Z (eds), Society and religion in the second temple period, 187-262. London: $\mathrm{W} H$ Allen.

Kressel, G M 1994. An anthropologist's response to the use of social science models in Biblical studies. Semeia 68, 153-161.

Levine, A-J \& Blickenstaff, M (eds) 2001. A feminist companion to Matthew. Sheffield: Sheffield Academic Press.

Maccini, R G 1994. A reassessment of the woman at the well in John 4 in light of the Samaritan context. JSNT 53, 35-64. 
Malina, B J \& Neyrey, J 1988. Calling Jesus names: The social value of labels in Matthew. Sonoma, CA: Polebridge Press.

Malina B J \& Rohrbaugh R L 1992. Social-science commentary on the synoptic gospels. Minneapolis, MN: Fortress Press.

Malina B J 1993a. The New Testament world: Insights from cultural anthropology. Rev ed. Louisville, KY: Westminster John Knox Press.

Malina B J 1993b. Windows on the world of Jesus: Time travel to ancient Judea. Louisville, KY: Westminster John Knox Press.

Malina B J 1996. The Social world of Jesus and the gospels. London: Routledge.

Malina B J 2001. The social gospel of Jesus: The kingdom of God in Mediterranean perspective. Minneapolis, MN: Fortress Press.

Menhe, $M L$ \& Kuye $N$ M, lettre de pardon de la $8^{\text {ème }}$ CEPAC adressée à la $37^{\text {ème }}$ CADC, Bukavu, 21 juillet 1997.

Moyise, S 2001. The Old Testament in the new: An introduction. London: Continuum.

Mutambo, J J 1997. Les Banyamulenge: Qui sont-ils? D'où viennent-ils? Quel rôle ont-ils joué (et pourquoi) dans le processus de la libération du Zaïre? Kinshasa: Imprimerie Saint Paul.

Neyrey, J H 1998. Honor and shame in the Gospel of Matthew. Louisville, KY: Westminster John Knox Press.

Neyrey, J H 1994. Despising the shame of the cross: Honor and shame in the Johannine passion narrative. Semeia 68, 113-133.

O'Day, R G 2001. Surprised by faith: Jesus and the Canaanite woman in Levine A-J \& Blickenstaff (ed), A feminist companion to Matthew, 115-125. Sheffield: Sheffield Academic Press.

Overman, J A 1990. Matthew's Gospel and formative Judaims: The social world of the Matthean community. Minneapolis, MN: Fortress Press.

Overman, J A 1996. Church and community in crisis: The Gospel according to Matthew. Valley Forge, PA: Trinity Press International.

Pilch, J J \& Malina, B J (eds) 1998. Handbook of biblical social values. Peabody, MA: Hendrickson Publishers.

Plevnik J 1998. Honor/shame, in Pilch, J J \& Malina, B J (eds), Handbook of biblical social values, 106-114. Peabody, MA: Hendrickson Publishers.

Rukundwa, S L 2003. The Banyamulenge community seen from social and biblical perspective. Unpublished MA thesis, University of Pretoria.

Rukundwa, S L 2004. The Banyamulenge of the Democratic Republic of Congo: A cultural community in the making. HTS 60(1\&2).

Saldarini, A J 1991. The Gospel of Matthew and Jewish-Christian conflict in Balch 1991:38-61.

Saldarini, A J 1994. Matthew's Christian-Jewish community. Chicago, IL: The University of Chicago Press.

Sim, D C 1998. The Gospel of Matthew and Christian Judaism: The history and social setting of the Matthean community. Edinburgh: T \& T Clark.

Stark, R 1991. Antioch as the social situation for Matthew's Gospel in Balch 1991:189-205.

Swartley, W M (ed) 1992. The love of enemy and nonretaliation in the New Testament. Louisville, KY: Westminster John Knox Press.

Tenney, M C 1982. New Testament survey. Grand Rapids, MI: Eerdmans. 
Ukpong J 2002a. Inculturation hermeneutics: An African approach to biblical interpretation, in Dietrich \& Luz 2002:17-32.

Ukpong J 2002b. The Story of Jesus' birth (Lk 1-2): An African reading, in Dietrich \& Luz 2002:59-70.

Wink, W 1992. Neither passivity nor violence: Jesus' third way (Mt 5:38-42), in Swartley 1992:102-125.

Wire, A C 1991. Gender in a scribal community, in Balch 1991:87-121. 